\title{
Screening of the Superlative Packaged Fruit Juices for Nutritional Values
}

\author{
Sunil Kumar Rai*
}

Student, Department of Biotechnology, Rapture Biotech, Noida, India

*Address for Correspondence: Mr. Sunil Kumar Rai, Student, Department of Biotechnology, Rapture Biotech, Noida Sector-10, India

E-mail: sunilraiself2015@gmail.com

Received: 10 June 2018/ Revised: 24 Oct 2018/ Accepted: 21 Dec 2018

\begin{abstract}
Background: The fruits are excellent source of balanced diet because it provides essential nutrients. The packaged juices claimed the high level of nutrition values, therefore the study focuses towards the parameters of purity and health nutrition has been concluded by screening the most popular fruit juices in India on various parameters.

Methods: The study deals with the analysis of best packaged fruit juices by identifying standard $\mathrm{pH}$ value using $\mathrm{pH}$ meter, microbial contamination ration on NAM, phytochemical properties, quantitative and adulteration analysis, significant amount of vitamins and minerals, and antimicrobial activity.

Results: The objective of this study was to assess the microbial quality of the fruit juices of different companies. The natural juices were beneficial for health on the basis of $\mathrm{pH}$ value. Tropicana pomegranate had the highest value in microbial contamination analysis $\left(2.3 \times 10^{3} \mathrm{cfu} / \mathrm{ml}\right)$. Tannin and flavonoid resist against the cancer and diabetes. Tropicana apple juice with protein lowest concentration $(60.33 \mu \mathrm{g} / \mathrm{ml})$ was beneficial. Real pomegranate with maximum phenol concentration (9.06 $\mu \mathrm{g} \mathrm{GAE} / \mathrm{ml}) \mathrm{was}$ beneficial against some diseases. Natural pomegranate with maximum carbohydrate concentration $(7.69 \mu \mathrm{g} / \mathrm{ml}) \mathrm{was}$ beneficial. Natural apple with the lowest tannin concentration $(-0.38 \mu \mathrm{g} \mathrm{TAE} / \mathrm{ml})$ was preferred. Real apple had the largest zone of inhibition $(20 \mathrm{~mm})$ shows maximum antimicrobial activity.

Conclusion: The data obtained from the study concluded that Real fruit juice somehow is good for consumption, conversely not suitable for long term and daily consumption because packaged juices become carcinogenic. The observations are probably not stable and get over-involved on long time storage.
\end{abstract}

Key-words: Adulteration, Antimicrobial activity, Packaged fruits juices, Phytochemical analysis, Nutrition values, Quantitative analysis, Secondary metabolites

\section{INTRODUCTION}

Nutrients like carbohydrates, proteins, fats, vitamins etc plays vital and specific role for the development of body. The study contract with verdict out different constituents and compositions of fruit juices and analyzing the category of nutrient available in foods helps to plan a balanced diet ${ }^{[1]}$. The juices of fruits are considered as highly preferred beverage universally to humans. Generally, it get conserved by applying chemicals as preservatives and as well as through the

\section{How to cite this article}

Rai SK. Screening of the Superlative Packaged Fruit Juices for Nutritional Values. SSR Inst. Int. J. Life. Sci., 2019; 5(1): 21842195.

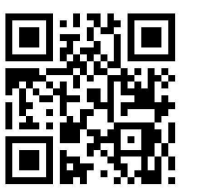

Access this article online www.ijlssr.com natural factors while production.

Somehow, the various microorganisms present in fruit juice generate "food-borne diseases" and may also cause death of patient. Fruit juices are very popular among the people of all ages around the world. Ready to drink packed fruit juice is becoming more and more popular. Advantage of packed fruit juices are that these are convenient to carry and can be kept for a considerable amount of time. Fruit juices by their very nature contain various organisms ${ }^{[2,3]}$. Clearly, many of these microorganisms will be harmless yeasts and saprophytic bacteria. By detecting this bacterial load in the juice, it apparently gives an about the quality of the sample ${ }^{[4]}$.

Basically Juices are processed by mechanic squeezing and blending of fresh fruits and vegetable flesh at room temperature without exposing to high temperature or solvents along with valuable nutrients comprises of 
vitamins and minerals to supply a vigorous diet ${ }^{[1,4]}$. A lot of marketable juices are refined to eliminate fiber or pulp although lofty pulp fresh apple juice is most accepted beverage. The fruit juices are generally distinguish into wide variety on the bases of their extraction and storage process. The concentrated fruit juices are highly well-liked means to extracted juices from the fruits moreover next the water content gets reduced (by evaporating process) ${ }^{[5,6]}$. The huge amounts of concentrated juices, generally frozen state are shipped to the other country for packaging and marketing. The fruit juice packaging companies reconstitute the juice by adding water before packaging. Another popular way to extract juice from the fruit in country of origin and then lightly pasteurized and frozen, chilled or aseptically transported to the country where it will be packed. Freshly squeezed juice extracted from the fruits and used immediately ${ }^{[7,8]}$.

The information provided through the study deals with testing different fruit juices samples to identify the components and chemicals presence. The studies were allowed to analysis the packaged juices at different parameters of health benefits, purity and hygiene. The study places an interest towards phytochemical analysis, quantitative analysis and adulteration. The study also highlights the antibacterial properties, antifungal properties as well as the microbial contamination ratio in the juices.

\section{MATERIALS AND METHODS}

Total six samples of fruit juices collected from local market of Noida, India in the duration of 2017. The samples required to perform the necessary tests are mentioned below, which includes some collection of Real and Tropicana juice and natural fresh marketed juice of required flavor Real apple, Tropicana apple, Natural apple, Real pomegranate, Tropicana pomegranate, and Natural pomegranate.

Determination of fruit juice's $\mathbf{p H}$ - The $\mathrm{pH}$ of healthy juice should be more then $\mathrm{pH}$ 3.5. For $\mathrm{pH}$ testing $\mathrm{pH}$ meter was used.

Detection of microbial contamination- In six samples of fruit juices, two varieties of fruit juices (Apple, Tropicana) were chosen based on the consumer demand. Samples were tested within an hour after purchased. About $0.1 \mathrm{ml}$ of all samples were uniformly spread onto the NAM and incubated for 24 hours at $37^{\circ} \mathrm{C}^{[9,10]}$. The plates were allow for screening to identify the presence of distinct colonies following incubation period along with the definite numbers of bacteria, were estimated as colony forming unit per $\mathrm{ml}(\mathrm{cfu} / \mathrm{ml})^{[11-15]}$.

Phytochemical analysis- For testing presence of fats takes clean test tube and added $1 \mathrm{ml}$ of each fruit juice samples. Using a pipette, added the $2 \mathrm{ml}$ of ethanol to each test tube. Stirrer with glass rod and added $2 \mathrm{ml}$ of distilled water in tube and stirrer again ${ }^{[11,17,18]}$.

Fats were present, if the solution turns in white color. For analyzing the cardiac glycoside, $1 \mathrm{ml}$ of all extract was treated glacial acetic acid of about $0.5 \mathrm{ml}$ that include one drop of solution of ferric chloride solution and underplayed with $0.2 \mathrm{ml}$ concentrated sulphuric acid. At the interface a brown ring formed and violet ring might be emerging beneath the ring whereas a greenish ring might be formed in the acetic acid layer.

For phenols, $2 \mathrm{ml}$ of distilled water was further added to $1 \mathrm{ml}$ of extract behind few drop of $10 \%$ aqueous ferric chloride.

For flavonoide analysis, dilute sodium hydroxide was added to $1 \mathrm{ml}$ of extract. An intense yellow color was produced in the plant extract, which become colorless on addition of a few drops of dilute nitric acid indicates the presence of flavonoide ${ }^{[16]}$. For tannin test, added 2 $\mathrm{ml}$ of $5 \%$ ferric chloride to $2 \mathrm{ml}$ of sample ${ }^{[9-11,19]}$.

For test saponins, added $2 \mathrm{ml}$ of sample to clean tube, using a pipette added $4-5 \mathrm{ml}$ of distilled water and noted for the stable froth formation indicates presence of saponins.

For analyzing protein, same amount of " $5 \%$ solution of sodium hydroxide" and " $1 \%$ copper sulphate was added". Here the pink or purple color indicates the occurrence of free amino acids and proteins.

For testing presence of benedict's, $1 \mathrm{ml}$ of a sample solution was placed in a test tube. Two $\mathrm{ml}$ of Benedict's reagent (A solution of $3.46 \mathrm{~g}$ sodium citrate, $2 \mathrm{~g}$ sodium carbonate and $0.346 \mathrm{~g}$ copper sulphate mixed with $20 \mathrm{ml}$ distilled water) was added ${ }^{[20,21]}$. Place test tube on water bath for $5 \mathrm{~min}$ and absorbed the color changes and formation of precipitate.

For fehling test, the $1 \mathrm{ml}$ of Fehling $A, 7 \%$ copper sulphate $\left(0.7 \mathrm{~g} \mathrm{CuSO}_{4}\right.$ in $10 \mathrm{ml}$ distilled water) and Fehling $\mathrm{B}, 25 \%$ sodium hydroxide, and $35 \%$ potassium titrate $(2.5 \mathrm{~g} \mathrm{NaOH}$ and $3.5 \mathrm{~g}$ potassium titrate in $10 \mathrm{ml}$ distilled water) solution were mixed and boiled for one 
minute. Similar amount of extract were added and allow to heat onto the boiling water bath for 5 - $10 \mathrm{~min}$. Appearance of the yellow colored first and then brick red colored precipitate revealed the presence of reducing agent. For mollsch's test, added $2 \mathrm{ml}$ of carbohydrate solution in a test tube and added then 2 drops of $\alpha$-naphthol solution ${ }^{[11]}$. Suspiciously incline the tubes and pour concentration $\mathrm{H}_{2} \mathrm{SO}_{4}$ using a dropper closer to the wall of test tubes.

\section{Quantitative analysis}

Estimation of protein by Lowry method- Prepare the standard BSA solutions from 0 to $1 \mathrm{mg} / \mathrm{ml}$ concentration in boiling test-tubes by suitably dilution of BSA stock solution. Keeps the volume of solution $5 \mathrm{ml}$. Added to the $2 \mathrm{ml}$ of Lowry reagent having $5 \mathrm{ml}$ of unknown sample test tube. Added $0.2 \mathrm{ml}$ of "Folins-ciocalteau reagent" and determine absorbance at $660 \mathrm{~nm}$ using spectrophotometer ${ }^{[18,19]}$. Plot a graph, with protein concentration and $x$-axis and absorbance at $y$-axis and prepare a standard calibration graph. Calculate the value of proteins in unknown samples by using slope value of the graph.

\section{Estimation of reducing sugars by the dinitro salicylic} acid (DNS) method- Taken 7 clean, dry test tubes and pipette out "standard sugar solution" ranges from 0 to 3 $\mathrm{ml}$ in different test tubes and constitute the volume to 3 $\mathrm{ml}$ with distilled water concentrations ranging from 0 to $750 \mathrm{mg}$ and then added $1 \mathrm{ml}$ DNS reagent and close the test tube with cotton plug after that keep the test tube onto the boiling water bath for 5 minutes later then kept the test tubes at room temperature ${ }^{[22]}$. Examined the extinction at $540 \mathrm{~mm}$ aligned with the blank. Prepared the standard curves of the sugars provided and use them to estimate the concentration of the unknowns provided.

Estimation of tannic acid- Added 0, 100, 200, 300 and $400 \mathrm{mg} / \mathrm{ml}$ of tannic acid working solution from standard in 4 test tubes and make up the volume to $5 \mathrm{~mL}$ using distilled water. About $2 \mathrm{ml}$ of reagent 1 was added to each test tube for analyzing absorbance within 10 minutes. Absorbance was observed at $605 \mathrm{~nm}$ for each sample by spectrophotometer ${ }^{[22,24]}$. Plot a graph, with protein concentration on $\mathrm{x}$-axis and absorbance on $\mathrm{y}$-axis Antimicrobial activity of different fruit juices by disc diffusion method- NAM for bacteria and PDA for fungus and prepare a standard calibration graph. Calculate the amount of tannic acid in unknown sample by using slope value of the graph.

Estimation of phenol- Standard gallic acid $(0,1,10,20$, $50 \mu \mathrm{g} / \mathrm{ml}$ ) was placed into the clean test tubes. Added distilled water to make up the volume up to $500 \mu \mathrm{L}$. Added $2.5 \mathrm{~mL}$ of "Folin-Ciocalteu's" reagent to each test tube and incubate at room temperature for $5 \mathrm{~min}{ }^{[18]}$. Added $2 \mathrm{ml}$ of $75 \% \quad \mathrm{Na}_{2} \mathrm{CO}_{3}$ to each test tube and incubate at room temperature for 1.5 hours ${ }^{[15]}$. Measure the absorbance of each sample at $765 \mathrm{~nm}$ using a spectrophotometer and maintaining protein conc. on $\mathrm{x}$-axis and absorbance on $\mathrm{y}$-axis to plot standard calibration graph and by using slope value of the graph Calculate the amount of phenols in unknown samples.

Adulterate analysis of fruit juices for sodium benzoate and formalin- Taken the $5 \mathrm{ml}$ of sample into a beaker along with $500 \mathrm{ul}$ of $10 \% \mathrm{NaOH}$ solution and $6 \mathrm{~g} \mathrm{NaCl}$. Added sufficient water to bring the volume up to about $50 \mathrm{ml}$ and let it stand for $30 \mathrm{~min}$ with frequent shaking [19]. Added one drop of phenolphthalein (ph. ph) (the color will change) and drops of $\mathrm{HCl}$ until the color change (disappear) than add excess $3 \mathrm{ml}$ of $\mathrm{HCl}$. Added $6.25 \mathrm{ml}$ of chloroform and transferred into separator funnel. Let it stand for 20 min with frequent shaking ${ }^{[17]}$. Transferred $12.5 \mathrm{ml}$ of the chloroform layer (lower layer) into a conical flask and then added $12.5 \mathrm{ml}$ of $50 \%$ ethanol solution followed by titrating with $0.05 \mathrm{M} \mathrm{NaOH}$ and added to the 1 drop of ph.ph as an indicator. For the analyzing presence of formalin, taken $1 \mathrm{ml}$ of sample in test tube and then about $500 \mu$ l of concentrated sulphuric acid was added to the side walls of the test tube without shaking ${ }^{[25,26]}$.

\section{Determination of Vitamin $\mathrm{C}$ by iodine titration-} Prepared to the solution of $1 \%$ starch solution and added $0.50 \mathrm{~g}$ soluble starch to $50 \mathrm{ml}$ boiling distilled water. For titrating with juice samples, added $25 \mathrm{ml}$ of juice sample to a beaker and then added about $1 \mathrm{ml}$ starch solution. Titrate until endpoint reached ${ }^{[20]}$. Recorded to the initial and final volume of iodine solution, required producing the color changed at the end point. Calculate the amount of titrate used for each flask ${ }^{[27]}$.

was prepared according to the accurate composition. Immediately after autoclaving, allowed it to cool in a 
$45-50^{\circ} \mathrm{C}$. Freshly prepared medium were pour into petri plates and allowed to cool to room temperature and stored at $4^{\circ} \mathrm{C}$. About $100 \mu \mathrm{L}$ of bacteria culture and $150 \mu \mathrm{L}$ of fungus from freshly prepared culture was taken in the pipette and poured in the middle of the respective petri plate ${ }^{[26,27]}$. Swab the bacteria and fungus evenly on the surface of the plate. Sterilized the forceps using a flame and dip in the samples and antibiotics for 5 - 10 seconds. Place to the each disc gently on the agar plate. Let the plate rest in laminar air flow for $\mathbf{3 0}$ minutes so that the drug is properly absorbed in the gel. Invert plates and incubate plates overnight at $30^{\circ} \mathrm{C}$.

\section{Calculation}

$$
\begin{gathered}
y=m x+c \\
x=(y-c) / m
\end{gathered}
$$

$y=y$ axis

$\mathrm{x}=\mathrm{x}$ axis

\section{RESULTS}

The research work had been conducted at the Department of Biotechnology, Rapture Biotech, Noida, India. In this study, most popular packaged juice samples were focused collected. Two varieties of fruit juices
(Apple, Tropicana) were chosen based on the consumer demand. Samples were tested within an hour after procurement.

Fruit juice having low $\mathrm{pH}$ tends to acidic nature. As we had determined the $\mathrm{pH}$ values of different fruit juices (apple, pomegranate) from different spices like natural with tropicana and real brands. It shows from Table 1, natural apple juice had $\mathrm{pH}$ value 3.8, was lowest in comparison to normal range is between (6 and 7.5). Optimally, we want a $\mathrm{pH}$ of 7.365. As same as natural pomegranate juice had $\mathrm{pH}$ value 3.8 and according to $\mathrm{pH}$ concentration the healthiest $\mathrm{pH}$ is one that is slightly alkaline. Natural (apple, pomegranate) was slightly approaching alkaline nature or less acidic, But tropicana apple had $\mathrm{pH}$ value 3.5 (which is near by the $\mathrm{pH}$ of natural juices) it can be beneficial with compare to Real (Table 1). Microbial contamination of juices shows the hygienic nature of the fruit juice. The juice contains the maximum value of contamination may be beneficial. Tropicana pomegranate has the highest value $\left(2.3 \times 10^{3}\right.$ $\mathrm{cfu} / \mathrm{ml}$ ) so it will may be beneficial in among all above fruit juices (Table 1).

\section{Microbial contamination of different fruit juice}

Table 1: Microbial contamination value of different fruit juice

$\begin{array}{lcccc}\text { S. No. } & \text { Different fruit juice } & \text { pH value } & \text { No. of colonies } & \text { cfu } / \mathrm{ml} \\ \text { 1. } & \text { Tropicana apple } & 3.5 & 15 & 1.5 \times 10^{3} \mathrm{cfu} / \mathrm{ml} \\ \text { 2. } & \text { Tropicana pomegranate } & 2.9 & 23 & 2.3 \times 10^{3} \mathrm{cfu} / \mathrm{ml} \\ \text { 3. } & \text { Real apple } & 3.1 & 15 & 1.5 \times 10^{3} \mathrm{cfu} / \mathrm{ml} \\ \text { 4. } & \text { Real pomegranate } & 3.3 & 9 & 0.9 \times 10^{3} \mathrm{cfu} / \mathrm{ml} \\ \text { 5. } & \text { Natural apple } & 3.8 & - & - \\ \text { 6. } & \text { Natural pomegranate } & 3.9 & - & - \\ & & & & \\ \end{array}$

Phytochemical analysis- Phytochemical test was performed on all sample juices, which includes fat test, cardiac glycoside test, phenol test, flavonoid test, tannin test, saponin test, protein test, bendicts test, Fehling test and mollish's test (Table 2). In case of apple juices saponin was highly present in natural apple juice and in 
case of pomegranate tannin and flavonoid were highly present in all three (Real, Tropicana and natural). Tannin and flavonoid resist against the disease cancer and diabetes, these are very beneficial for health. Protein estimation test was performed on all samples to find out the exact amount of protein present in the juice sample.
Highest concentration of protein present in the real pomegranate juice $(332.6 \mu \mathrm{g} / \mathrm{ml})$ was the beneficial among all other juices. Tropicana apple juice with protein concentration $(60.33 \mu \mathrm{g} / \mathrm{ml})$ was the lowest concentration.

Table 2: Qualitative phytochemical analysis of apple juice and Pomegranate juice

\begin{tabular}{|c|c|c|c|c|c|c|c|}
\hline S No. & $\begin{array}{c}\text { Phytochemical } \\
\text { Test }\end{array}$ & $\begin{array}{c}\text { Pomegranate } \\
\text { natural }\end{array}$ & $\begin{array}{c}\text { Natural } \\
\text { apple }\end{array}$ & $\begin{array}{c}\text { Pomegranate } \\
\text { real }\end{array}$ & $\begin{array}{c}\text { Real } \\
\text { apple }\end{array}$ & $\begin{array}{c}\text { Pomegranate } \\
\text { tropicana }\end{array}$ & $\begin{array}{c}\text { Tropicana } \\
\text { apple }\end{array}$ \\
\hline 1. & Fat & $+/-$ & $+/-$ & - & - & + & - \\
\hline 2. & $\begin{array}{l}\text { Cardiac } \\
\text { glycoside }\end{array}$ & - & - & - & - & + & + \\
\hline 3. & Phenol & ++ & + & ++ & - & ++ & - \\
\hline 4. & Flavonoid & +++ & ++ & ++ & $+/-$ & +++ & ++ \\
\hline 5. & Tannin & +++ & ++ & +++ & + & +++ & - \\
\hline 6. & Saponnin & + & +++ & ++ & - & ++ & + \\
\hline 7. & Protein & ++ & ++ & + & + & + & + \\
\hline 8. & Benedict's & $\begin{array}{c}\text { Dark/Brown } \\
\text { ppt. }\end{array}$ & Brown & Brick Red & Red & $\begin{array}{c}\text { Green/Yellow } \\
\text { ppt. }\end{array}$ & $\begin{array}{c}\text { Orange/Red } \\
\text { ppt. }\end{array}$ \\
\hline 9. & Fehling & ++ & +++ & ++ & + & + & ++ \\
\hline 10. & Mollisch's & + & ++ & +++ & + & ++ & + \\
\hline
\end{tabular}

(+= Slight present, $++=$ Moderate present, $+++=$ Highly present, $-=$ Absent,$+/=$ Maybe present)

Highest concentration of protein present in the real pomegranate juice $(332.6 \mathrm{\mu g} / \mathrm{ml})$ was beneficial among all other juices. Tropicana apple juice with protein concentration (60.33) was lowest concentration (Fig. 1). Not everyone needs the same amount of protein. Protein was modest 0.8 grams of proteins per kilogram of body weight.

Carbohydrates were present in about every living thing and co-operates a significant role in the appropriate performance of the immune system, fertilization, blood clotting, and individual's growth. Carbohydrates provide energy to body, with minerals and vitamins. Simple carbohydrate reduction involves, reducing amount of carbohydrate consumed to between 5 to $45 \%$ of daily calories. Natural pomegranate with maximum concentration $(7.69 \mu \mathrm{g} / \mathrm{ml})$ of carbohydrate was the beneficial for health but real pomegranate (3.47 $\mu \mathrm{g} / \mathrm{ml}$ ) has more beneficial in compare to Tropicana (Fig. 2). 


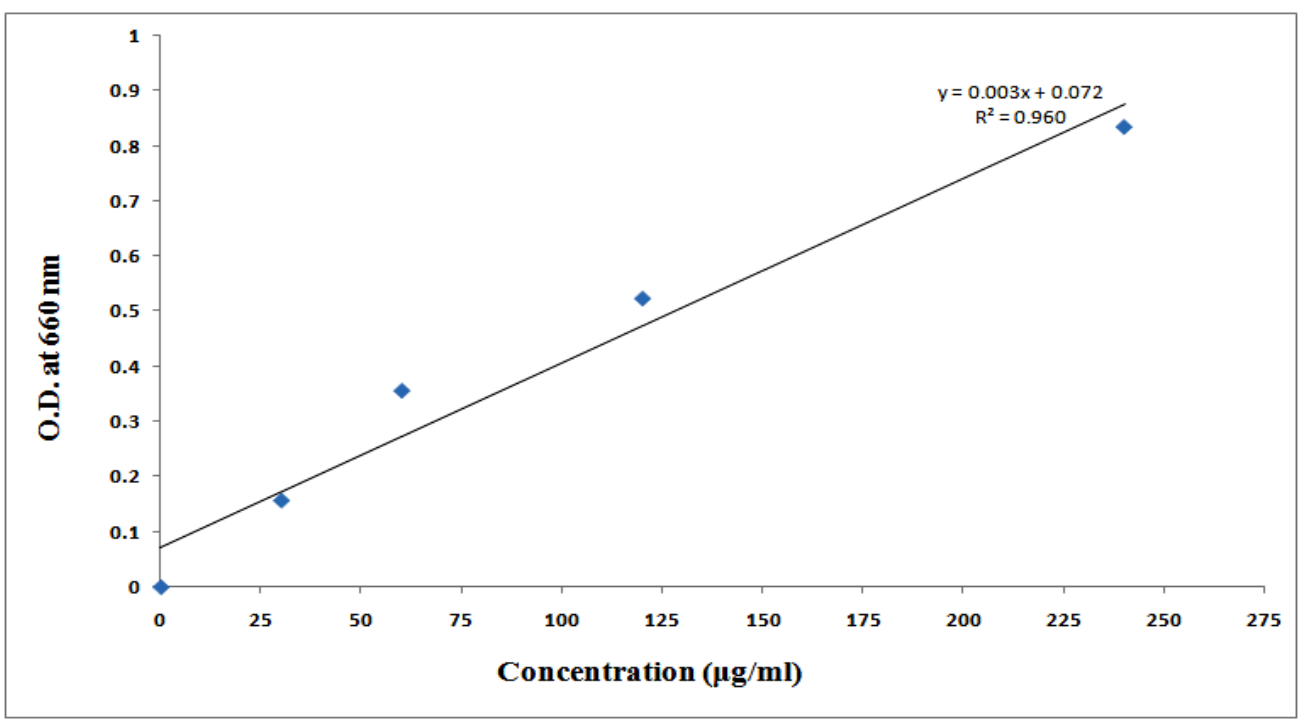

Fig. 1: Quantitative estimation of Protein from different fruit juices

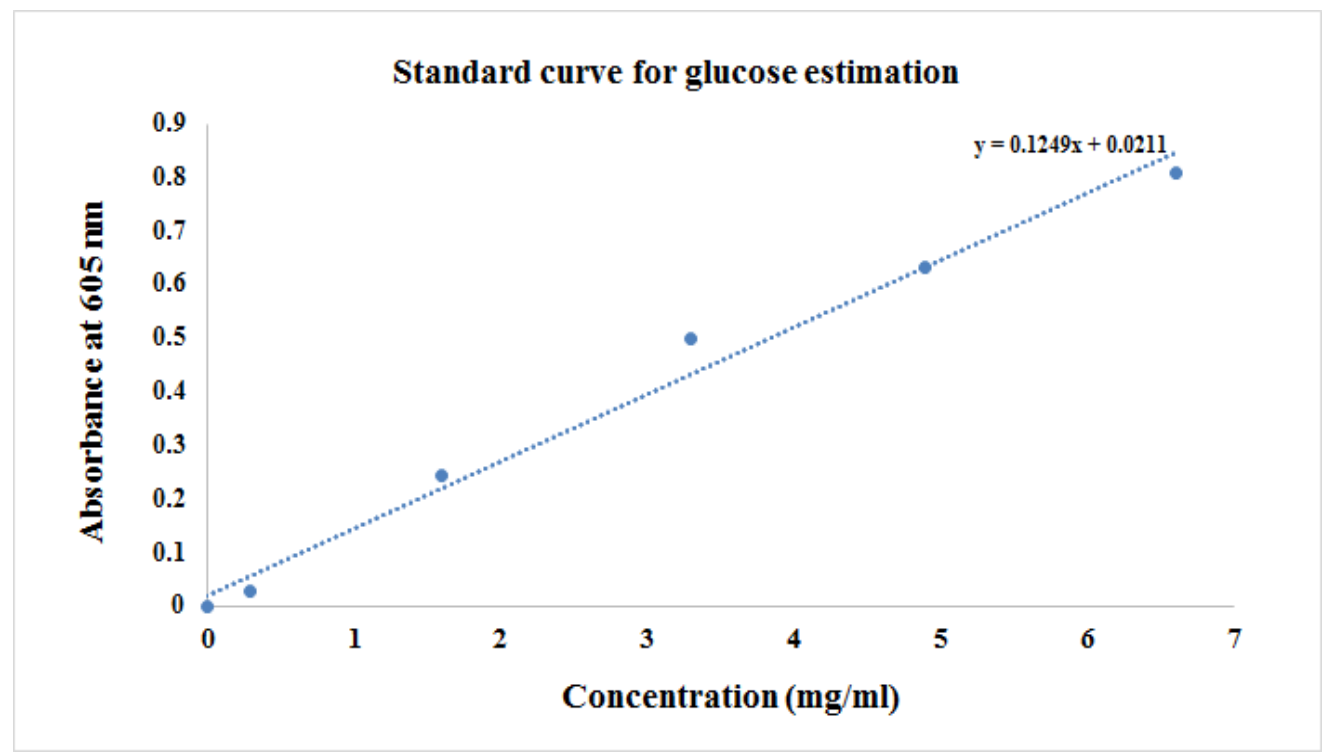

Fig. 2: Quantitative estimation of Carbohydrate from different fruit juices

The use of concentrated phenol for skin may root the severe damage of skin. Phenol had huge benefits such as preservation, decreasing the risk of cardiovascular diseases, cancer, diabetes, Alzheimer's disease and arthritis. Real pomegranate with maximum concentration $(12.03 \mu \mathrm{g} \mathrm{GAE} / \mathrm{ml})$ of phenol was more beneficial with compare to Tropicana (Fig. 3). High amount of polyphenol in take with $30 \%$ reduction the mortality (rate of death) in older adults.

Tannins was commonly referred to as tannic acid and had been accounted to be conscientious for reduction in food intake, growth rate, food efficiency, total metabolizable energy and protein digestion.
Consequently, the foods that are rich in tannins were measured to be of low nutrition. Additionally tannin too reported to exert other physiological property as it increase blood clotting, decrease blood pressure, fall in serum lipid level, develop liver necrosis, and adjust immune-responses. The amount and variety of tannins was dangerous to these belongings. Natural apple juice had lowest concentration $(0.38 \mu \mathrm{g} \quad \mathrm{TAE} / \mathrm{ml})$ was preferred fruit juice but real apple juice with concentration (32.5 $\mu \mathrm{g} \mathrm{TAE} / \mathrm{ml}$ ) was better than Tropicana (Fig. 4). 


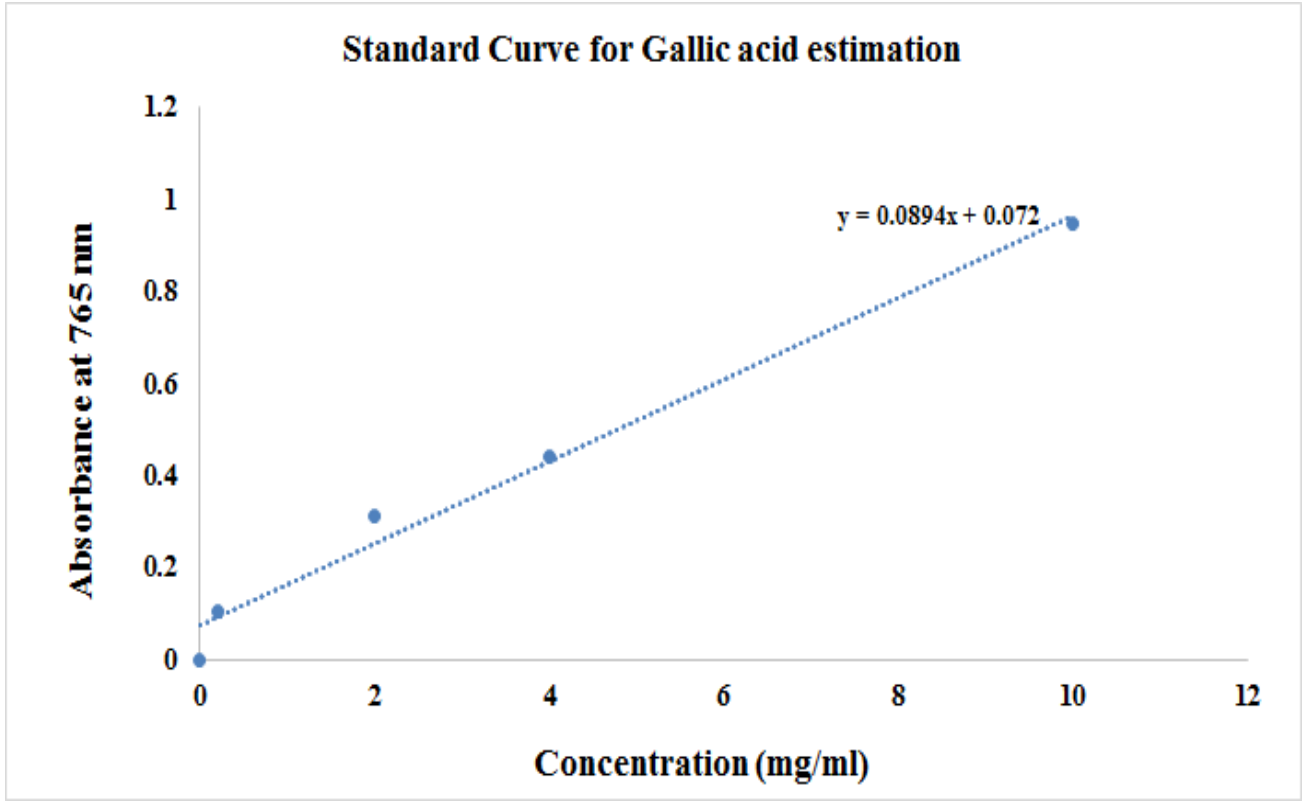

Fig. 3: Quantitative estimation of Gallic acid from different fruit juices

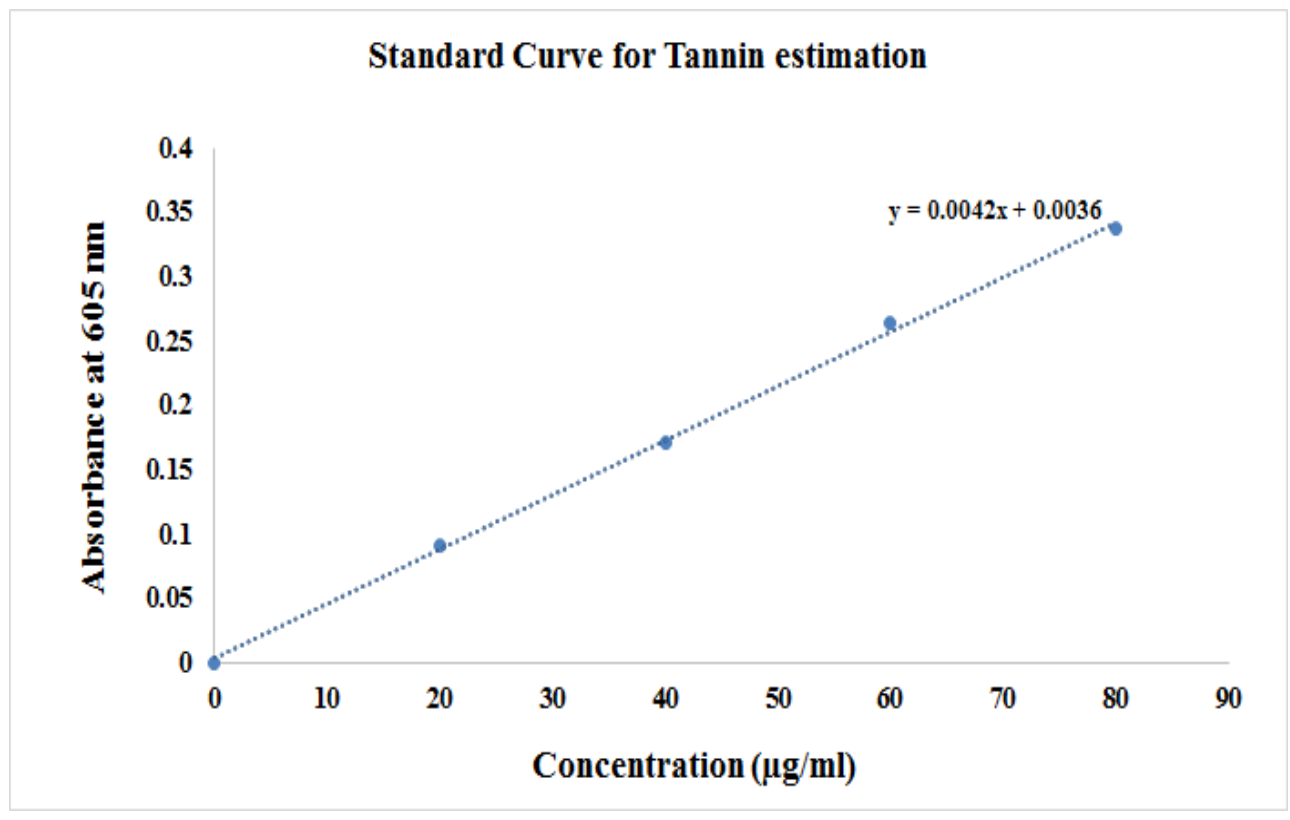

Fig. 4: Quantitative estimation of tannin from different fruit juices

Analysis of sodium benzoate and formalin- Sodium benzoate was used to preserve the fruit juice for the long period of time; it might be the cause to asthma and cancer disease. If sodium benzoate is present in highly amount then there will be a negative effect on health. About $1,500 \mathrm{mg}$ of sodium is daily requirement of old age and high blood pressure patient and less than 2,300 milligrams of sodium in a day for rest of them. Both natural apple and pomegranate consist of slightly $0.21 \%$ of sodium benzoate. As same as in real apple the presence of sodium benzoate was very less $0.21 \%$, so real apple juice was more beneficial compare to the Tropicana juice. Formalin was a preservative and can preserve juice for long time. Due to high toxicity, it was considered to cause liver and kidney. As per the experiment formalin was absent from all fruit juices so formalin had the negative effect on the health, it is good to avoid. Ascorbic acid titration was performed to find out the amount of Vitamin C in all sample juices (Table 3). 
Table 3: Consist of data obtained during the Ascorbic acid titration

S. No. Different juice Initial titration $(\mathrm{ml}) \quad$ Final titration $(\mathrm{ml}) \quad$ Difference $(\mathrm{ml})$

\begin{tabular}{|c|c|c|c|c|}
\hline 1. & Tropicana apple & 24.4 & 46.3 & 21.6 \\
\hline 2. & Real apple & 43.5 & 48.3 & 4.8 \\
\hline 3. & Natural apple & 44 & 49.5 & 5.5 \\
\hline 4. & Tropicana pomegranate & 46 & 49.8 & 3.8 \\
\hline 5. & Real pomegranate & 45.9 & 46.1 & 0.2 \\
\hline 6. & Natural pomegranate & 46 & 47 & 1 \\
\hline
\end{tabular}

The real pomegranate has higher zone of inhibition for bacteria 1 (B. Subtilis) (4 $\mathrm{mm})$ \& bacteria 2 (S. Flexneri) (10 mm) (Fig. 5). Real apple has the largest zone of

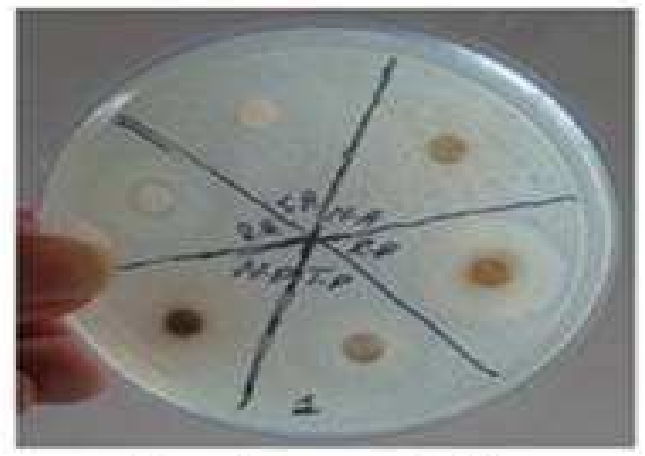

Bacillus subtilis

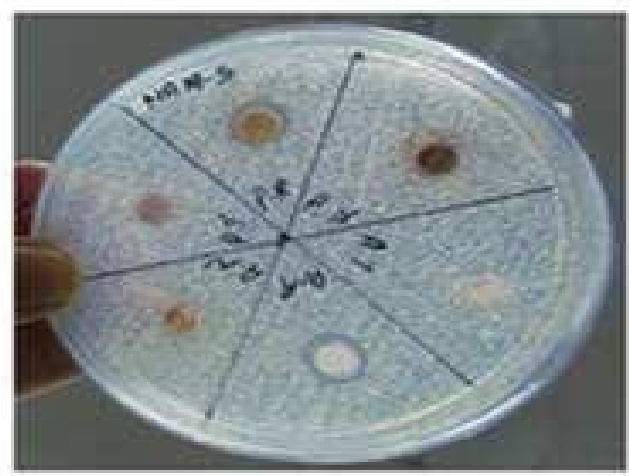

E. coli inhibition (20 mm) (Fig. 6), the most beneficial juice in among all above.

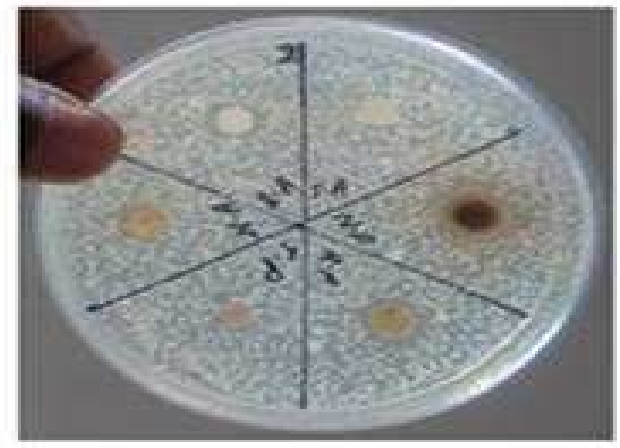

Shigella flexneri

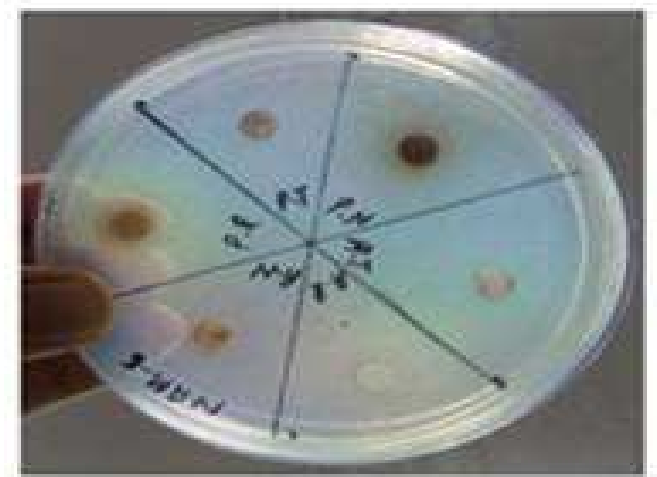

Enterobacter cloacae 


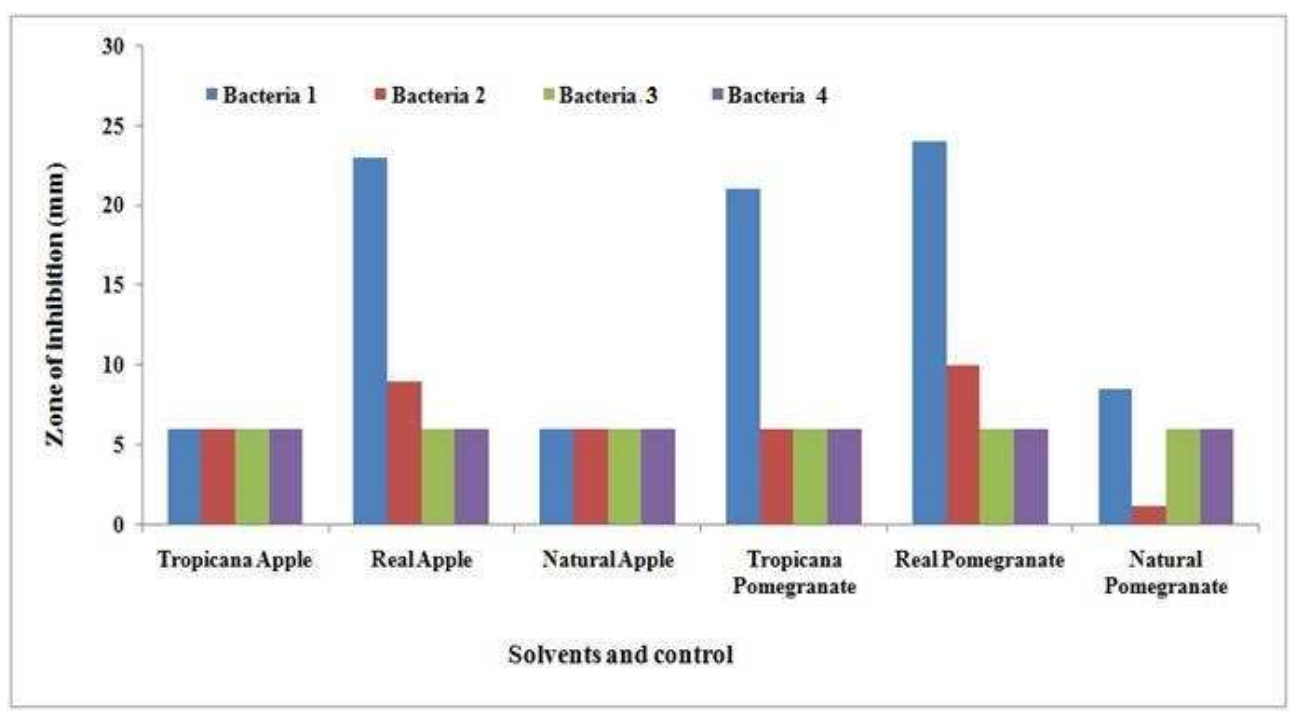

Fig. 5: Disk diffusion result of different fruit juices again four isolated Bacteria Bacteria 1- Bacillus subtilis, Bacteria 2- Shigella flexneri Bacteria 3- E. coli, Bacteria 4- Enterobacter cloacae

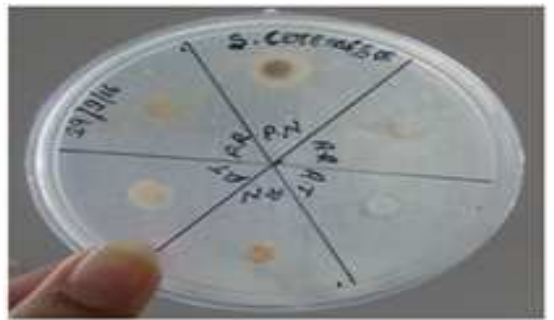

Saccharomyces cerevisiae

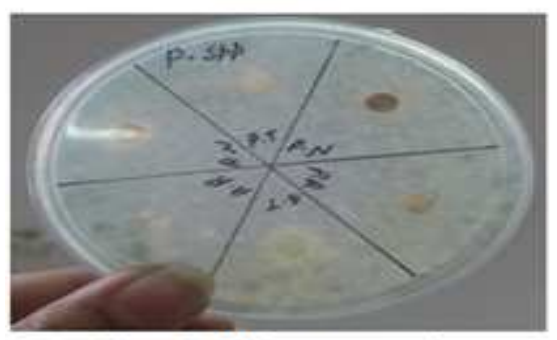

Pericillimm species

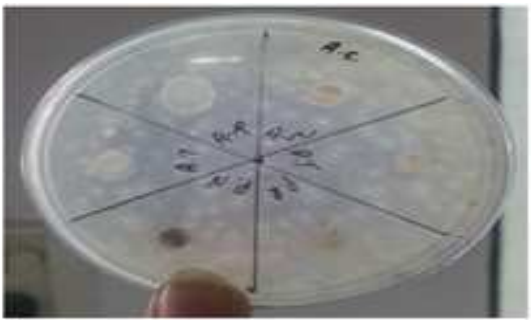

Aspergillus cardidus

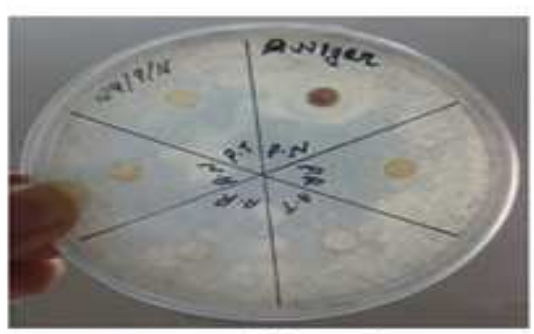

Aspergillus niger

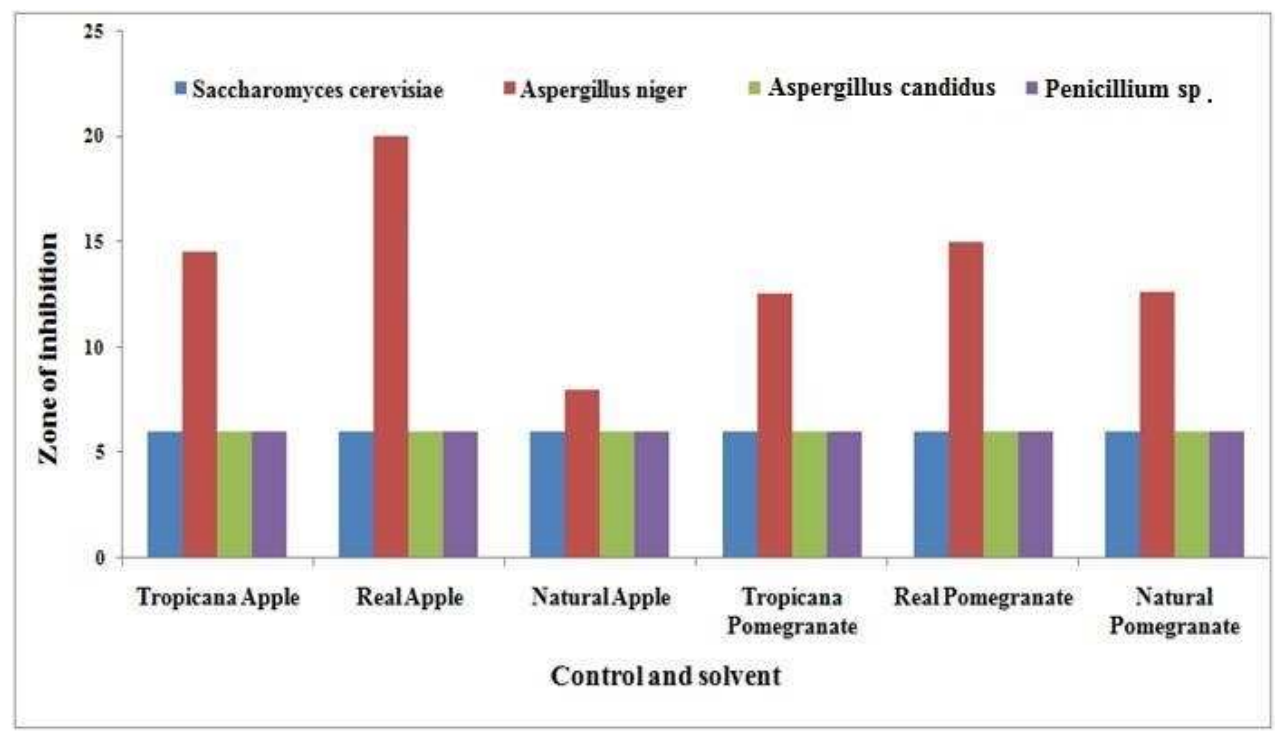

Fig. 6: Disk diffusion result of different fruit juices again four isolated Fungi 


\section{DISCUSSION}

There were six fruit juice samples collected: Natural apple, Natural pomegranate juice, Real apple, Real pomegranate juice, Tropicana apple, and Tropicana pomegranate juice to perform the analysis. Initially the $\mathrm{pH}$ of all sample juices were checked, by taking some sample juice in bicker and pouring the $\mathrm{pH}$ meter in this, the result is in both natural juices apple $(\mathrm{pH} 3.8)$ and pomegranate $(\mathrm{pH} 3.8) \mathrm{pH}$ value is high (means less acidic in nature). So the natural juices were beneficial for health on the basis of $\mathrm{pH}$ test compare to other juices ${ }^{[26]}$. Sometimes the juices were packaged in hygienic manner to increase the sustainability of juices for long period but according to health issues it has the negative effect on the health so to find out the quantity of compounds we performed the microbial contamination on the packaged juices real and tropicana. Tropicana pomegranate has the highest value in microbial contamination analysis $\left(2.3 \times 10^{3} \mathrm{cfu} / \mathrm{ml}\right)$.

Phytochemical test was performed on all sample juices, which includes fat test, cardiac glycoside test, phenol test, flavonoid test, tannin test, saponin test, protein test, bendicts test, Fehling test and mollish's test ${ }^{[19]}$. In case of apple juices saponin was highly present in natural apple juice and in case of pomegranate tannin and flavonoid were highly present in all three (Real, Tropicana and natural) ${ }^{[8]}$. Tannin and flavonoid resist against the disease cancer and diabetes, these are very beneficial for health. Protein estimation test was performed on all samples to find out the exact amount of protein present in the juice sample. Highest concentration of protein present in the real pomegranate juice $(332.6 \mathrm{\mu g} / \mathrm{ml})$ was the beneficial among all other juices. Tropicana apple juice with protein concentration $(60.33 \mu \mathrm{g} / \mathrm{ml})$ was the lowest concentration.

Quantitative analysis for phenol was performed to find the exact concentration of phenol present in the sample. Phenol had a number of negative submission like skin damage even though phenol have even more beneficial effects such as preventing and/or decreasing the risk of cardiovascular diseases, cancer, diabetes, alzheimer's disease, and arthritis [27]. Real pomegranate with maximum concentration (9.06 $\mu \mathrm{g} \mathrm{GAE} / \mathrm{ml}$ ) of phenol can be beneficial against some disease. Quantitative analysis of carbohydrate was performed on all samples to find out the concentration of carbohydrate in sample juices.
Carbohydrate is the main nutrient for the health. It played a vital function in the appropriate performance of the immune system, fertilization, blood clotting, and human development ${ }^{[24]}$. Natural pomegranate with maximum concentration $(7.69 \mu \mathrm{g} / \mathrm{ml})$ of carbohydrate is the beneficial for health rather than any others. The quantitative estimation of tannin was carrying out with each and every juice sample to locate out except concentration of tannin. Occasionally, tannin has been accounted to be liable for diminish in feed ingestion, growth rate, feed efficiency, total metabolized energy and protein digestion ability ${ }^{[9,17]}$. Consequently, the foods with high amount of tannins are measured to be of low nutritional values. Similarly pr equivalently tannin furthermore reported to apply additional physiological possessions, such as blood clotting acceleration, blood pressure reduction, fall in serum lipid level, produce liver necrosis and alter immune-responses ${ }^{[23]}$. The quantity and variety of tannins are serious to these properties. The Natural apple juice with the lowest concentration $(-0.38 \mu \mathrm{g} T A E / m l)$ was the preferred fruit juice.

Adulterant analysis of sodium benzoate and formalin was performed on samples to find out the percentage of sodium benzoate ${ }^{[11]}$. Tropicana apple consist of $2.55 \%$ of sodium Benzoate. If Sodium Benzoate will present in highly amount then there will be a negative effect on health. Formalin was additionally a preservative and can protect juices for long duration. Due to high toxicity, it was considered to cause liver and kidney ${ }^{[22]}$. As per the experiment formalin was absent from all fruit juices. So formalin has the negative effect on the health, it is good to avoid.

Ascorbic acid titration was performed to find out the amount of "Vitamin C" in all sample juices. "Vitamin C" is the master vitamin for our health ${ }^{[9]}$. The amount of vitamin $C$ should be high in daily diet for proper growth and functionality of body. Antimicrobial activity was performed on all samples against different bacteria and fungi. Zone of inhibition represents the presence of antibacterial. Higher zone of inhibition is beneficial against the bacteria and fungi. Some disease like typhoid, TB etc is mainly caused by Bacillus bacteria and some other bacterial sp. Real pomegranate has higher zone of inhibition for bacteria 1 (B. Subtilis) was $24 \mathrm{~mm}$ and bacteria 2 (S. Flexneri) was $10 \mathrm{~mm}$ so it is most beneficial for these types of diseases. Real apple has the largest zone of inhibition $(20 \mathrm{~mm})$, which represents the 
maximum presence of antibacterial against the fungi, also the most beneficial juice in among all above.

\section{CONCLUSIONS}

Human body requests significant nutrients to uphold the vigorous condition. The food must include good quality of nutrients. This study sentenced out the variety of ingredients and composition of fruit juice. The data illustrate that natural juices are beneficial for health on the basis of $\mathrm{pH}$ test compare. Tropicana pomegranate juice has highest microbial contamination value. Tannin and flavonoid resist against cancer and diabetes. Highest concentration of protein present in the real pomegranate juice. Real pomegranate juice with maximum concentration of phenol fights against few diseases. Natural pomegranate with maximum concentration of carbohydrate is valuable. Natural apple with the lowest concentration of tannins is most appropriate. Formalin has the negative effect on the health and good to avoid. Real pomegranate has higher zone of inhibition for B. Subtilis and S. Flexneri, so it is most beneficial for diseases caused by the bacteria. The Real apple juices have the largest zone of inhibition.

In recent years packaged fruit juices becoming first by consumers and demanded more day by day. However the packaged juice has some limitations regarding balanced nutrition. Nowadays consumers have astonishing preference towards health and take option. However if the nutrition level of jutes were protected by using some natural ingredient may improve the consumption by consumers. The packaged juice sector may introduce improvement for the consumer and product.

\section{ACKNOWLEDGMENTS}

I would like to offer my sincere thanks to Dr. Faiyaz Ahmed, department of Biotechnology of Bhimrao Ambhedkar University, Muzafferpur, India. I am also indebted thanks to Dr. Vinod Kumar Gupta, Rapture Biotech, Noida for their precious support in carrying out this work.

\section{CONTRIBUTION OF AUTHORS}

All authors equally contributed in this article.

\section{REFERENCES}

[1] Alvarez S, Riera FA, Alvarez R, Coca J, Cuperus FP, et al. A new integrated membrane process for producing clarified apple juice and apple juice aroma concentrate. J. Food Eng., 2000; 109-25.

[2] Thygesen LG, Lokke MM, Micklander E, Engelsen SB. Vibrational microspectroscopy of food Raman vs. FTIR. Tre. Food Sci. Tech., 2003; 50-57.

[3] Al-jedah JH, Robinson RK. Nutritional value and microbiological safety of fresh fruit juices sold through retail outlets in Qatar, Pakistan. J. Nutr., 2001; 1: 79-81.

[4] Lewis JE, Rao BN, Chaganti K, Thompson P. Human Bacteria in street vended Fruit Juices: A case study of Visakhapatnam City, India. Int. J. Food Safety, 2006; 8: 35-38.

[5] He K, Hu FB, Colditz GA, Manson JE, Willett WC, et al. Changes in intake of fruits and vegetables in relation to risk of obesity and weight gain among middle-aged women. Int. J. Obes. Rel. Metab. Disord., 2004; 28: 1569-74.

[6] Birkhed D. Sugar Content, Acidity and Effect on Plaque $\mathrm{pH}$ of Fruit Juices, Fruit Drinks, Carbonated Beverages and Sport Drinks. Car. Res., 1984; 18(2): 120-27.

[7] Rouseff RL. Bitterness in foods and beverage. Dev. Food Sci., 1990; 25: 1-12.

[8] Skinner JD, Carruth BR, Moran J, Houck K, Colletta F. Fruit juice intake is not related to children's growth. Pediatrics., 1999; 103: 58-64.

[9] Block G, Patterson B, Subat A. Fruit, vegetable, and cancer prevention: a review of the epidemiological evidence. Nut. \& Cancer, 1992; 18(1): 01-29.

[10]Disch A, Schwender J, Muller C, Lichtenthaler HK, Rohmer M. Distribution of the mevalonate and glyceraldehyde phosphate/ pyruvate pathways for isoprenoid biosynthesis in unicellular algae and the cyanobacterium Synechocystis PCC 6714. Biochem. J., 1998; 333: 381-88.

[11]Rangkadilok N, Sitthimonchai S, Worasuttayangkurn L, Mahidol C, Ruchirawat M, et al. Evaluation of free radical scavenging and antityrosinase activities of standardized longan fruit extract. Food \& Chem. Toxico., 2007; 45: 328-36.

[12]Murakami T, Hishi A, Matsuda H, Yoshikawa M. Medicinal Foodstuffs XVII. Fenugreek Seed. (3): Structures of new furostanol-type steroid saponins, Trigoneosides Xa, Xb, Xib, XIla, XIIb and XIIIa from the seeds of Egyptian Trigonella foenum-graecum L. Chem. \& Pharm. Bulletin., 2000; 48(7): 994-1000. 
[13]Roy PK, Munshi JD. Effect of saponin extracts on oxygen uptake and haematology of an air-breathing Climbing uerch, Anabas testudineus (Bloch). J. Freshwater Bio., 1989; 1: 167-72.

[14]Tripathy KD. Cardiac glycosides and drugs for CHF. In Essentials of medical pharmacology, $5^{\text {th }}$ ed., 2003; pp. 472-85.

[15]Masse BM, Granger CB. Cardiac failure. Current Medical diagnosis and treatment, $44^{\text {th }}$ ed., 2005; pp. 374-86.

[16] Wegener T, Fintelmann V. Flavonoids and bioactivity. Wein Med. Wochem. Schr., 1999; 149: 241-47.

[17]Robak J, Gryglewski RJ. Bioactivity of flavonoids. Pol. J. Pharmacol., 1996; 48: 555-64.

[18]Balasundram NK, Sundram, Samman S. Phenolic compounds in plants and agri-industrial by-products: Antioxidant activity, occurrence, and potential uses. Food Chem., 2006; 99: 191-203.

[19]Basu N, Rastogi RP. Triterpenoid saponins and sapogenins. Phytochemistry, 1967; 6: 1249-70.

[20]Raphael TJ, Kuttan G. Effect of naturally occurring triterpenoids glycyrrhizic acid, ursolic acid, oleanolic acid and nomilin on the immune system. Phytomedicine, 2003; 10: 483-89.
[21]Kolodziej $\mathrm{H}$, Kiderlen AF. Antileishmanial activity and immune modulatory effects of tannins and related compounds on Leishmania parasitised RAW 264.7 cells. Phytochemistry, 2005; 66: 2056-71.

[22]Lowry OH, Rosebrough NJ, Farr AL, Randall RJ. The original method. J. Biol. Chem., 1951; 193: 265.

[23]Basu $A$, Rhone $M$, et al. Berries: emerging impact on cardiovascular health. Nut. Rev., 2010; 68: 168-77.

[24]Levine $M$, Dhariwal KR, Wang $Y$, Park JB. Determination of optimal vitamin $C$ requirements in humans. Am. J. Clin. Nut., 1995; 62: 1347S-56S.

[25] Melander C, Andersson E, Axelsson S, Gorton L. Determination of reducing ends with flow injection analysis with amperometric detection: application to enzyme-hydrolysed methyl cellulose. Anal. Bioanal. Chem., 2007; 387(7): 2585-93.

[26]Ferreira D, Gross GG, Hagerman AE, Kolodziej H, Yoshida T. Tannins and related polyphenols: Perspectives on their chemistry, biology, ecological effects, and human health protection. Phytochem., 2008; 69: 3006-08.

[27]Bendich A. Vitamin C safety in humans. In: Packer L, Fuchs J, eds. Vitamin $C$ in health and disease. New York: Marcel Dekker Inc., 1997; 367-79. 